\title{
АНАЛИЗ СОВРЕМЕННОЙ ДЕМОГРАФИЧЕСКОЙ СИТУАЦИИ В РОССИЙСКОЙ ФЕДЕРАЦИИ
}

\author{
(c) 2018 Бабич Светлана Гаврииловна \\ кандидат экономических наук, доцент кафедры статистики \\ Российский экономический университет имени Г.В. Плеханова \\ 117997, г. Москва, Стремянный пер., 36 \\ E-mail: Babich.SG@rea.ru \\ (c) 2018 Ярных Эльвира Аркадьевна \\ доктор экономических наук, профессор кафедры статистики \\ Российский экономический университет имени Г.В. Плеханова \\ 117997, г. Москва, Стремянный пер., 36 \\ E-mail: Yarnykh.EA@rea.ru
}

В статье представлены результаты изучения динамики численности населения в Российской Федерации и федеральных округах страны. Рассмотрено изменение возрастной и региональной структуры населения; произведен анализ изменения среднего возраста одного жителя в стране и ее регионах. Произведен анализ основных показателей рождаемости, смертности и естественного прироста (убыли) населения в РФ и регионах страны. Произведена группировка субъектов РФ по величине коэффициента естественного прироста (убыли) населения.

Ключевые слова: население, рождаемость, смертность, естественный прирост (убыль), средний возраст; коэффициент рождаемости; общий коэффициент смертности; коэффициент естественного прироста (убыли) динамика, структура.

На социально-экономическое развитие отдельных территорий и страны в целом оказывают влияние различные внутренние и внешние факторы. Одним из важнейших внутренних факторов является сложившаяся в регионе демографическая ситуация. Под демографической ситуацией обычно понимают демографическую обстановку, состояние демографических процессов, состава и размещения населения в определенное время в стране или отдельном регионе [4, с. 41]. Экономическое развитие страны в условиях перехода на инновационную модель экономики во многом зависит от демографической ситуации, которая оказывает существенное влияние на формирования и состав рабочей силы. Под влиянием демографических процессов происходит возобновление трудовых ресурсов по различным количественным и качественным характеристикам, что является одним из необходимых условий расширенного воспроизводства. Данные процессы непосредственно воздействуют на результаты экономической деятельности общества, на социальные аспекты развития государства [6, с. 41].

Сокращение рождаемости означает сниже- ние численности рабочей силы, что приводит в итоге к увеличению демографической нагрузки на трудоспособное население. В то же время, уменьшение численности активной трудоспособной части населения приведет к невозможности не только количественного, но и качественного воспроизводства высоко квалифицированных профессиональных кадров.

По предварительным данным Росстата численность населения нашей страны по состоянию на 1 января 2018 г. составила 146,9 млн. чел., что на 4976,4 тыс. чел. (на 3,5\%) больше, чем в начале 2009 г., и на 76,0 тыс. чел. (на $0,05 \%$ ) больше аналогичного показателя предшествующего года.

В течение рассматриваемого периода в пяти федеральных округах - Центральном, Ceверо-Западном, Южном, Северо-Кавказском и Уральском - отмечается рост численности населения. Если, например, в Центральном федеральном округе рост данного показателя составил 5,9\%, то в Уральском федеральном округе - только $0,8 \%$. Наибольшее увеличение численности населения (на 2727,2 тыс. чел. или на 19,9\%) произошло в Южном федеральном округе, в основном, за счет присоединения Кры- 
ма (табл. 1).

Как видно из табл. 1, в трех федеральных округах - Приволжском, Сибирском и Дальневосточном - численность населения снизилась, причем в Дальневосточном федеральном округе в наибольшей степени - на 4,6\%.

В региональной структуре населения наибольший удельный вес составляет Центральный федеральный округ, удельный вес которого в течение рассматриваемого периода незначительно возрос с 26,2\% до 26,8\%. Если доля Северо-Западного федерального округа не изменилась и составила 9,5\%, то в наибольшей степени возрос удельный вес численности населения Южного федерального округа с 9,7\% до 11,2\% (на 1,5 п.п.), a, например, доля Приволжского федерального округа сократилась с 21,3\% до 20,1\% (табл. 2).

K началу 2018 г. по сравнению с январем 2009 г. региональная структура населения страны не претерпела существенных изменений, что подтверждает значение рассчитанного коэффициента (индекса) структурных различий
Рябцева (IR), составил 0,027, т.е. наблюдается тождественность сравниваемых региональных структур.

В течение 2017 г. численность населения страны возросла 76060 чел., в основном, за счет миграционного прироста, который составил 211878 чел. (естественная убыль населения достигла в стране 135818 чел.). Превышение числа умерших над числом родившихся (т.е. естественная убыль населения) в 2017 г. отмечается в большинстве федеральных округов страны, и только в двух федеральных округах - Северо-Кавказском и Уральском - наблюдается естественный прирост населения, составив 73053 чел. и 10063 чел. соответственно. В то же время в Центральном, Северо-Западном, Южном и Уральском федеральных округах отмечается миграционный прирост населения, т.е. превышение числа прибывших в соответствующий регион над числом выбивших из него (табл. 3).

В 2017 г. снижение общей численности населения отмечается в 59 регионах (71,95\%), а в

Таблица 1. Динамика численности населения в федеральных округах РФ

\begin{tabular}{|l|c|c|c|c|}
\hline \multirow{2}{*}{} & \multicolumn{2}{|c|}{$\begin{array}{c}\text { Численность населения на начало } \\
\text { года, тыс. чел. }\end{array}$} & \multicolumn{2}{c|}{$\begin{array}{c}\text { Изменение численности населения, } \\
\text { тыс. чел. }\end{array}$} \\
\cline { 2 - 5 } & 2009 г. & 2018 г. & тыс. чел. & $\%$ \\
\hline Российская Федерация & 141904,0 & 146880,4 & 4976,4 & 3,5 \\
\hline Центральный & 37121,8 & 39311,4 & 2189,6 & 5,9 \\
\hline Северо-Западный & 13462,3 & 13952,0 & 489,7 & 3,6 \\
\hline Южный & 13714,6 & 16441,8 & 2727,2 & 19,9 \\
\hline Северо-Кавказский & 9186,9 & 9823,5 & 636,6 & 6,9 \\
\hline Приволжский & 30157,8 & 29542,7 & $-615,1$ & $-2,0$ \\
\hline Уральский & 12255,0 & 12356,2 & 101,2 & 0,8 \\
\hline Сибирский & 19545,5 & 19287,5 & -258 & $-1,3$ \\
\hline Дальневосточный & 6460,1 & 6165,3 & $-294,8$ & $-4,6$ \\
\hline
\end{tabular}

Источник. Составлено и рассчитано по данным Росстата.

Таблица 2. Распределение населения РФ по федеральным округам

\begin{tabular}{|l|c|c|c|}
\hline \multirow{2}{*}{} & \multicolumn{2}{|c|}{ Удельный вес численности населения на начало } & $\begin{array}{c}\text { Изменение удельного } \\
\text { веса, п.п. }\end{array}$ \\
\cline { 2 - 4 } & 2009 г. & 2018 г. & - \\
\hline Российская Федерация & 100,0 & 100,0 & 0,6 \\
\hline Центральный & 26,2 & 26,8 & 0,0 \\
\hline Северо-Западный & 9,5 & 9,5 & 1,5 \\
\hline Южный & 9,7 & 11,2 & 0,2 \\
\hline Северо-Кавказский & 6,5 & 6,7 & $-1,2$ \\
\hline Приволжский & 21,3 & 20,1 & $-0,2$ \\
\hline Уральский & 8,6 & 8,4 & $-0,7$ \\
\hline Сибирский & 13,8 & 13,1 & $-0,4$ \\
\hline Дальневосточный & 4,6 & 4,2 & \\
\hline
\end{tabular}

Источник. Составлено и рассчитано по данным Росстата. 
23 субъектах (28,05\%) число проживающих в них возросло. В 58 субъектах страны (70,73\%) наблюдается естественная убыль населения, а в 24 регионах $(29,27 \%)$ - естественный прирост населения. В 54 субъектах РФ $(65,85 \%)$ отмечается превышение числа выбывающих из регионов над числом прибывших в них, а в 28 регионах (34,15\%) - миграционный прирост населения.

При сравнении возрастной структуры населения РФ в начале 2018 г. по сравнению с январем 2009 г. несмотря на увеличение числа жителей страны отдельных возрастных групп, необходимо отметить сокращение численности трудоспособного населения в возрасте 15-29 лет и 45-54 лет (табл. 4).

Существенной проблемой в стране является старение населения. К началу 2018 г. по сравнению с январем 2009 г. число граждан в возрасте старше 60 лет увеличилось с 24,7 млн. чел. до 31,2 млн. чел. (на 26,6\%), а их удельный вес в общей

Таблица 3. Компоненты изменения численности населения РФ, человек

\begin{tabular}{|l|c|c|c|c|c|}
\hline \multirow{2}{*}{} & \multicolumn{2}{|c|}{$\begin{array}{c}\text { Численность населения } \\
\text { на начало года, человек }\end{array}$} & \multicolumn{2}{|c|}{ Изменение численности населения, человек } \\
\cline { 2 - 6 } & 2017 г. & 2018 г. & $\begin{array}{c}\text { естественный } \\
\text { прирост }\end{array}$ & $\begin{array}{c}\text { миграционный } \\
\text { прирост }\end{array}$ & общий прирост \\
\hline РФ & 146804372 & 146880432 & -135818 & 211878 & 76060 \\
\hline в федеральных округах: & & & & & 101831 \\
\hline Центральный & 39209582 & 39311413 & -96663 & 198494 & 52693 \\
\hline Северо-Западный & 13899310 & 13952003 & -23538 & 76231 & 13394 \\
\hline Южный & 16428458 & 16441852 & -30866 & 44260 & 47711 \\
\hline Северо-Кавказский & 9775770 & 9823481 & 73053 & -25342 & -93878 \\
\hline Приволжский & 29636574 & 29542696 & -59166 & -34712 & 10426 \\
\hline Уральский & 12345803 & 12356229 & 10063 & 363 & -38722 \\
\hline Сибирский & 19326196 & 19287474 & -8420 & -30302 & -17395 \\
\hline Дальневосточный & 6182679 & 6165284 & -281 & -17114 & -174 \\
\hline
\end{tabular}

Источник. Составлено и рассчитано по данным Росстата.

Таблица 4. Распределение численности населения РФ п возрастным группам на начало года

\begin{tabular}{|c|c|c|c|c|c|c|}
\hline & & \multicolumn{4}{|c|}{ Численность населения на начало года } & \multirow{3}{*}{$\begin{array}{c}\text { Темп роста } \\
\text { численности } \\
\text { населения,\% }\end{array}$} \\
\hline \multicolumn{2}{|c|}{ Возраст, лет } & \multicolumn{2}{|c|}{2009 г. } & \multicolumn{2}{|c|}{2018 г. } & \\
\hline & & человек & \% к итогу & человек & \% к итогу & \\
\hline 0 & 4 & 7691932 & 5,4 & 9347026 & 6,4 & 21,5 \\
\hline 5 & 9 & 6643265 & 4,7 & 8873083 & 6,0 & 33,6 \\
\hline 10 & 14 & 6757230 & 4,8 & 7597511 & 5,2 & 12,4 \\
\hline 15 & 19 & 9260943 & 6,5 & 6815936 & 4,6 & $-26,4$ \\
\hline 20 & 24 & 12572538 & 8,9 & 7335814 & 5,0 & $-41,7$ \\
\hline 25 & 29 & 11892997 & 8,4 & 11119860 & 7,6 & $-6,5$ \\
\hline 30 & 34 & 10679795 & 7,5 & 12765648 & 8,7 & 19,5 \\
\hline 35 & 39 & 9853394 & 6,9 & 11424758 & 7,8 & 15,9 \\
\hline 40 & 44 & 9400944 & 6,6 & 10453459 & 7,1 & 11,2 \\
\hline 45 & 49 & 11682383 & 8,2 & 9499564 & 6,5 & $-18,7$ \\
\hline 50 & 54 & 11197091 & 7,9 & 9372342 & 6,4 & $-16,3$ \\
\hline 55 & 59 & 9600108 & 6,8 & 11049384 & 7,5 & 15,1 \\
\hline 60 & 64 & 5772885 & 4,1 & 9782917 & 6,7 & 69,5 \\
\hline 65 & 69 & 5481053 & 3,9 & 7936998 & 5,4 & 44,8 \\
\hline 70 & 74 & 5718023 & 4,0 & 3919500 & 2,7 & $-31,5$ \\
\hline 75 & 79 & 3863537 & 2,7 & 4520884 & 3,1 & 17,0 \\
\hline 79 & 84 & 2686815 & 1,9 & 2908602 & 2,0 & 8,3 \\
\hline 85 & 90 & 1149046 & 0,8 & 2157146 & 1,5 & 87,7 \\
\hline
\end{tabular}

Источник. Составлено и рассчитано по данным Росстата. 
численности населения страны возрос за этот же период с $17,4 \%$ до $21,3 \%$.

Средний возраст одного жителя страны увеличился в течение рассматриваемого периода с 38,28 лет до 39,34 лет. В федеральных округах страны значения среднего возраста одного жителя различаются, но во всех отмечается рост данного показателя. В начале 2009 г. и 2018 г. наибольший средний возраст одного жителя наблюдается в Центральном федеральном округе, который увеличился с 40,38 лет до 41,15 лет (на 0,77 лет). А наиболее «молодые» граждане проживают в Северо-Кавказском федеральном округе, средний возраст которого возрос с 33,50 лет до 34,33 лет (рис. 1).

Изменение возрастной структуры населения страны в целом и в отдельных федеральных округах обусловили изменения распределения населения по состоянию трудоспособности. Если в начале 2009 г. в стране 15,88\% населения были моложе трудоспособного возраста, то к началу 2018 г. данный показатель возрос до 18,56\%. Удельный вес трудоспособного населения сократился с $62,91 \%$ до 56,01\%; а лиц старше трудоспособного возраста увеличился с $21,21 \%$ до $25,44 \%$.

Аналогичная ситуация прослеживается и в регионах страны, т.е. происходит увеличение численности населения за пределами трудоспособного возраста и сокращение числа граждан в трудоспособном возрасте. В наименьшей степени удельный вес населения в трудоспособном возрасте сократился в Южном и Северо-Кавказском федеральных округах с 61,1\% до 55,3\% (на 5,8 п.п.) и с $62,0 \%$ до $57,8 \%$ (на 4,2 п.п.) соответственно, то Уральском и Сибирском федеральных округах снижение данного показателя составило 8,2 п.п. и 8,0 п.п. соответственно (табл. $5)$.

Сокращение доли населения в трудоспособном возрасте приведет к значительному росту

\section{Дальневосточный \\ Сибирский \\ Уральский}

Приволжский

Северо-Кавказский

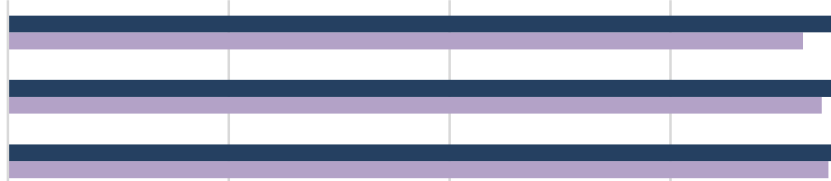

Южный

Северо-Западный

Центральный
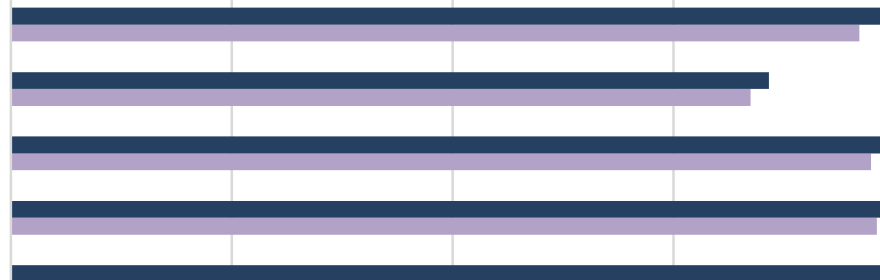

0

10

20

30

40

50

2018 г. $\quad 2009$ г.

лет

Puc. 1. Динамика среднего возраста одного жителя в федеральных округах РФ на начало года, лет

Таблица 5. Распределение населения РФ по возрастным группам на начало года

\begin{tabular}{|l|c|c|c|c|c|c|}
\hline \multirow{2}{*}{ Федеральный округ } & \multicolumn{5}{|c|}{ Удельный вес населения на начало года в возрасте,\% } \\
\cline { 2 - 7 } & моложе трудоспособного & \multicolumn{2}{c|}{ трудоспособного } & \multicolumn{2}{c|}{ старше трудоспособного } \\
\cline { 2 - 7 } & 2009 г. & 2018 г. & 2009 г. & 2018 г. & 2009 г. & 2018 г. \\
\hline Центральный & 13,7 & 16,2 & 62,2 & 56,2 & 24,1 & 27,6 \\
\hline Северо-Западный & 14,3 & 16,9 & 63,4 & 56,5 & 22,3 & 26,6 \\
\hline Южный & 15,9 & 18,1 & 61,1 & 55,3 & 23,1 & 26,6 \\
\hline Северо-Кавказский & 22,6 & 24,3 & 62,0 & 57,8 & 15,4 & 17,9 \\
\hline Приволжский & 15,8 & 18,5 & 62,8 & 55,2 & 21,4 & 26,3 \\
\hline Уральский & 16,7 & 20,4 & 64,3 & 56,1 & 19,0 & 23,5 \\
\hline Сибирский & 17,2 & 20,5 & 63,7 & 55,7 & 19,1 & 23,8 \\
\hline Дальневосточный & 17,3 & 19,8 & 65,0 & 57,8 & 17,7 & 22,4 \\
\hline
\end{tabular}

Источник. Составлено и рассчитано по данным Росстата. 
нагрузки на одного работающего как пожилыми людьми, так и детьми [7, с. 40].

Распределение населения по возрастным группам во многом обусловлено естественными и миграционными процессами, происходящими в РФ. Как отмечалось выше, негативной тенденцией современной демографической ситуации в большинстве регионов страны является естественная убыль населения в результате снижение рождаемости и компенсация потери населения миграционным приростом.

Начиная с 2009 г. до 2017 г. в стране наблюдалось увеличение числа родившихся. Причем, наибольший рост данного показателя происходил в 2014 г. и 2015 г.- на 10,3\% и 10,2\% соответственно. А в течение 2017 г. число родившихся в стране снизилось по сравнению с 2009 г. на 71380 чел. (на 4,1\%). В течение рассматриваемого периода в отдельные периоды по сравнению с предыдущими годами также отмечалось сокращение числа родившихся, наиболее существенное из которых произошло в 2017 г. - на 198422 чел. (на 10,5\%) (табл. 6).

В федеральных округах наблюдается различная динамика числа родившихся в течение рассматриваемого периода. Только в трех федеральных округах - Центральном, Северо-Западном и Южном число родившихся увеличилось, а в остальных федеральных округах данный показатель снизился. Наибольший рост числа родившихся отмечается в Южном федеральном округе - на 18435 чел. (на 11,3\%), в основном, за счет присоединение Крыма. А наиболее значительное уменьшение числа родившихся в относительном выражении произошло в Сибирском и Дальневосточном федеральных округах - на 13,2\% и 10,9\% соответственно (табл. 7).

Поскольку изучение динамики абсолютных показателей демографической статистики не в полной мере характеризуют сложившуюся ситуацию, то целесообразно, по нашему мнению, произвести анализ относительных показателей. Общий коэффициент рождаемости, показывающий число родившихся в регионе в течение ка-

Таблица 6. Динамика числа родившихся в РФ

\begin{tabular}{|c|c|c|c|c|c|}
\hline \multirow{2}{*}{ Год } & \multirow{2}{*}{$\begin{array}{c}\text { Число родившихся, } \\
\text { человек }\end{array}$} & \multicolumn{2}{|c|}{$\begin{array}{c}\text { Изменение числа родившихся по } \\
\text { сравнению с 2009 г. }\end{array}$} & \multicolumn{2}{c|}{$\begin{array}{c}\text { Изменение числа родившихся по } \\
\text { сравнению с предыдущим годом }\end{array}$} \\
\cline { 3 - 6 } & человек & $\%$ & человек & - \\
\hline 2009 & 1761687 & 0 & 0,0 & - & 1,5 \\
\hline 2010 & 1788948 & 27261 & 1,5 & 27261 & 0,4 \\
\hline 2011 & 1796629 & 34942 & 2,0 & 7681 & 5,9 \\
\hline 2012 & 1902084 & 140397 & 8,0 & -6262 & $-0,3$ \\
\hline 2013 & 1895822 & 134135 & 7,6 & 46861 & 2,5 \\
\hline 2014 & 1942683 & 180996 & 10,3 & -2104 & $-0,1$ \\
\hline 2015 & 1940579 & 178892 & 10,2 & -51850 & $-2,7$ \\
\hline 2016 & 1888729 & 127042 & 7,2 & -198422 & $-10,5$ \\
\hline 2017 & 1690307 & -71380 & $-4,1$ & & \\
\hline
\end{tabular}

Источник. Составлено и рассчитано по данным Росстата.

Таблица 7. Динамика числа родившихся в федеральных округах РФ

\begin{tabular}{|l|c|c|c|c|}
\hline & \multicolumn{2}{|c|}{ Число родившихся, человек } & \multicolumn{2}{c|}{ Изменение числа родившихся } \\
\hline Федеральный округ & 2009 г. & 2017 г. & человек & 2,3 \\
\hline Центральный & 400644 & 409945 & 9301 & 1,9 \\
\hline Северо-Западный & 151712 & 154603 & 2891 & 11,3 \\
\hline Южный & 163419 & 181854 & 18435 & $-6,8$ \\
\hline Северо-Кавказский & 157573 & 146894 & -10679 & $-9,5$ \\
\hline Приволжский & 364290 & 329821 & -34469 & $-7,0$ \\
\hline Уральский & 166808 & 155184 & -11624 & $-13,2$ \\
\hline Сибирский & 273469 & 237361 & -36108 & $-10,9$ \\
\hline Дальневосточный & 83772 & 74645 & -9127 & \\
\hline
\end{tabular}

Источник. Составлено и рассчитано по данным Росстата. 
лендарного года в расчете на 1000 человек населения, сократился в течение рассматриваемого периода в РФ с 12,4 до 11,5.

Во всех федеральных округах страны в 2017 г. по сравнению с 2009 г. общий коэффициент рождаемости снизился. В Центральном, Северо-Западном и Южном федеральных округах, в которых возросло число родившихся за изучаемый период, в расчете на каждую 1000 человек населения число родившихся также сократилось. И в Северо-Кавказском федеральном округе, который традиционно является регионом с высоким уровнем рождаемости, отмечается наиболее существенное сокращение общего коэффициента рождаемости - с 17,1 до 15,0 (рис. 2).

В субъектах РФ наблюдается значительная дифференциация по величине общего коэффициента рождаемости. По данным Росстата за 2017 г. минимальные значения общего коэффициента рождаемости наблюдается в Ленинград- ской области $(8,3)$ и Республике Мордовия $(8,5)$, а максимальные значения - в Чеченской Республике $(22,0)$ и Республике Тыва $(21,9)$.

Уровень рождаемости населения зависит от численности женщин в репродуктивном возрасте. По данным Росстата в 2017 г. в РФ численность женщин в возрасте от 15 до 49 лет составляла 34906 тыс. чел., что на 7,1\% меньше аналогичного показателя 2009 г., а их удельный вес в общем численности населения страны сократился с $26,5 \%$ до $23,8 \%$.

На фоне снижения рождаемости необходимо отметить о сокращение смертности населения. В целом в РФ число умерших снизилось в 2017 г. по сравнению с 2009 г. на 184418 чел. (на 9,2\%), а по сравнению с предшествующим годом уменьшилась на 64890 чел. (на 3,4\%) (табл. 8).

Сокращение числа умерших в 2017 г. по сравнению с 2009 г. отмечается во всех федеральных округах, кроме Южного федерального

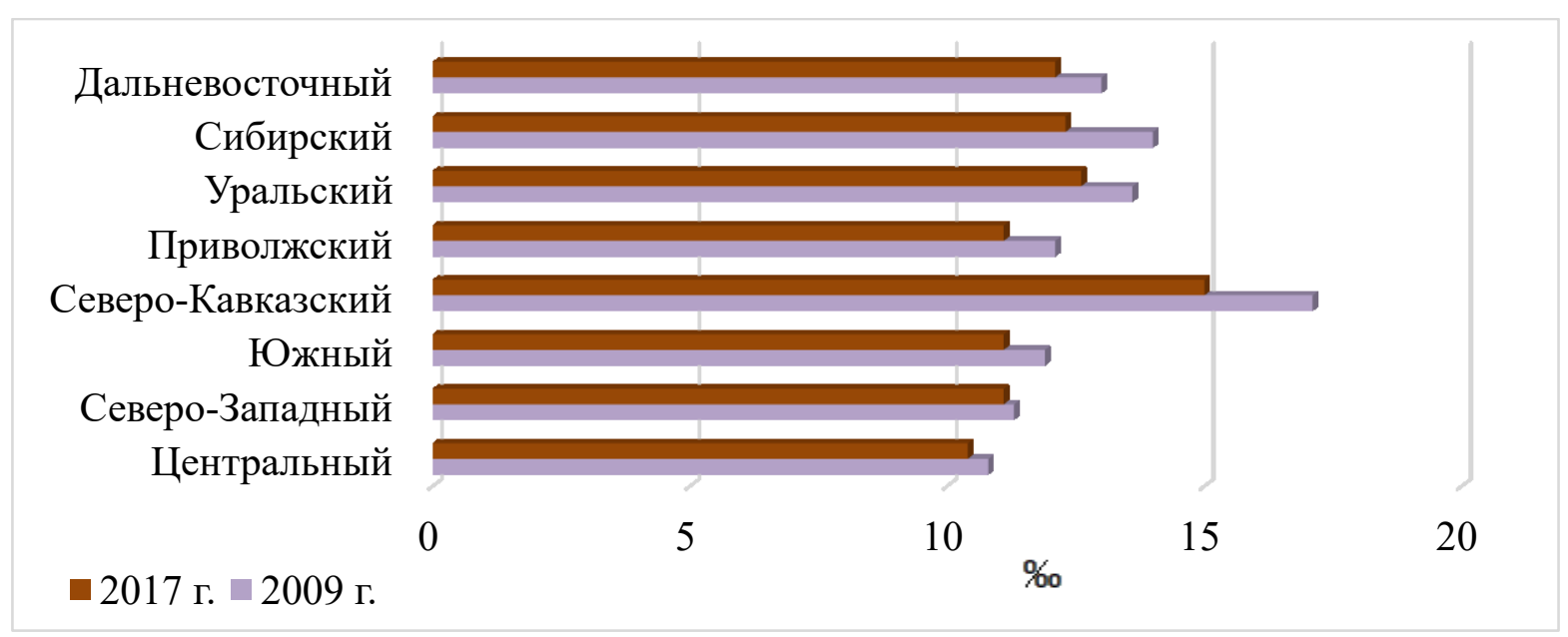

Puc. 2. Динамика общего коэффициента рождаемости в федеральных округах РФ, промилле

Таблица 8. Динамика числа умерших в РФ

\begin{tabular}{|c|c|c|c|c|c|}
\hline \multirow{2}{*}{ Год } & \multirow{2}{*}{$\begin{array}{c}\text { Число умерших, } \\
\text { человек }\end{array}$} & \multicolumn{2}{|c|}{$\begin{array}{c}\text { Изменение числа умерших } \\
\text { по сравнению с 2009 г. }\end{array}$} & \multicolumn{2}{c|}{$\begin{array}{c}\text { Изменение числа умерших } \\
\text { правнению с предыдущим годом }\end{array}$} \\
\cline { 2 - 6 } & человек & $\%$ & человек & - \\
\hline 2009 & 2010543 & 0 & 0,0 & 17973 & 0,9 \\
\hline 2010 & 2028516 & 17973 & 0,9 & -102796 & $-5,1$ \\
\hline 2011 & 1925720 & -84823 & $-4,2$ & -19385 & $-1,0$ \\
\hline 2012 & 1906335 & -104208 & $-5,2$ & -34526 & $-1,8$ \\
\hline 2013 & 1871809 & -138734 & $-6,9$ & 40538 & 2,2 \\
\hline 2014 & 1912347 & -98196 & $-4,9$ & -3806 & $-0,2$ \\
\hline 2015 & 1908541 & -102002 & $-5,1$ & -17526 & $-0,9$ \\
\hline 2016 & 1891015 & -119528 & $-5,9$ & -64890 & $-3,4$ \\
\hline 2017 & 1826125 & -184418 & $-9,2$ & & \\
\hline
\end{tabular}

Источник. Составлено и рассчитано по данным Росстата. 
округа, в котором данный показатель увеличился на 19464 чел. (на 10,1\%). А, например, в Северо-Западном и Дальневосточном федеральных округах число умерших снизилось в наибольшей степени - на 12,9\% и 12,4\% (табл. 9).

Общий коэффициент смертности, показывающих число умерших в течение календарного года в расчете на 1000 человек населения, сократился в РФ с 14,2 в 2009 г. до 12,4 в 2017 г., что, несомненно, является позитивной тенденцией. Во всех федеральных округах отмечается снижение общего коэффициента смертности населения (рисунок 3).

В субъектах РФ наблюдается значительная дифференциация по величине общего коэффициента смертности. По данным Росстата за 2017 г. минимальные значения общего коэффициента смертности наблюдаются в Республике Ингушетия $(3,2)$ и Чеченской Республике $(4,6)$, а максимальные значения - в Новгородской $(17,1)$ и Псковской $(17,4)$ областях.
В РФ коэффициент естественного прироста населения сократился в течение рассматриваемого периода с $-1,8$ до $-0,9$. В федеральных округах страны значение данного коэффициента различается. Если в 2009 г. в трех федеральных округах - Северо-Кавказском, Уральском и Сибирском - наблюдался естественный прирост населения, то в 2017 г. только в двух федеральных округах - Северо-Кавказском и Уральском сохраняется превышение числа родившихся над числом умерших в расчете на 1000 человек населения на 7,5 чел. и 0,9 чел. соответственно (рисунок 4).

О сложной демографической ситуации в стране в 2017 г. свидетельствует тот факт, что в 58 регионах (из 82 субъектов) наблюдается естественная убыль населения. Наиболее значительная естественная убыль населения в расчете на 1000 человек населения отмечается в Псковской $(7,9)$, Тульской $(7,6)$, Тверской $(7,0)$ и Новгородской $(6,8)$ областях. В 2017 г. только в 24

Таблица 9. Динамика числа умерших в федеральных округах РФ

\begin{tabular}{|l|c|c|c|c|}
\hline \multirow{2}{*}{} & \multicolumn{2}{|c|}{ Число умерших, человек } & \multicolumn{2}{c|}{ Изменение числа умерших } \\
\cline { 2 - 5 } & 2009 г. & 2017 г. & человек & $-11,8$ \\
\hline Центральный & 574534 & 506608 & -67926 & $-12,9$ \\
\hline Северо-Западный & 204586 & 178141 & -26445 & 10,1 \\
\hline Южный & 193256 & 212720 & 19464 & $-9,9$ \\
\hline Певеро-Кавказский & 81969 & 73841 & -8128 & $-11,7$ \\
\hline Уральский & 440281 & 388987 & -51294 & $-8,2$ \\
\hline Сибирский & 158107 & 145121 & -12986 & $-9,7$ \\
\hline Дальневосточный & 272248 & 245781 & -26467 & $-12,4$ \\
\hline
\end{tabular}

Источник. Составлено и рассчитано по данным Росстата.

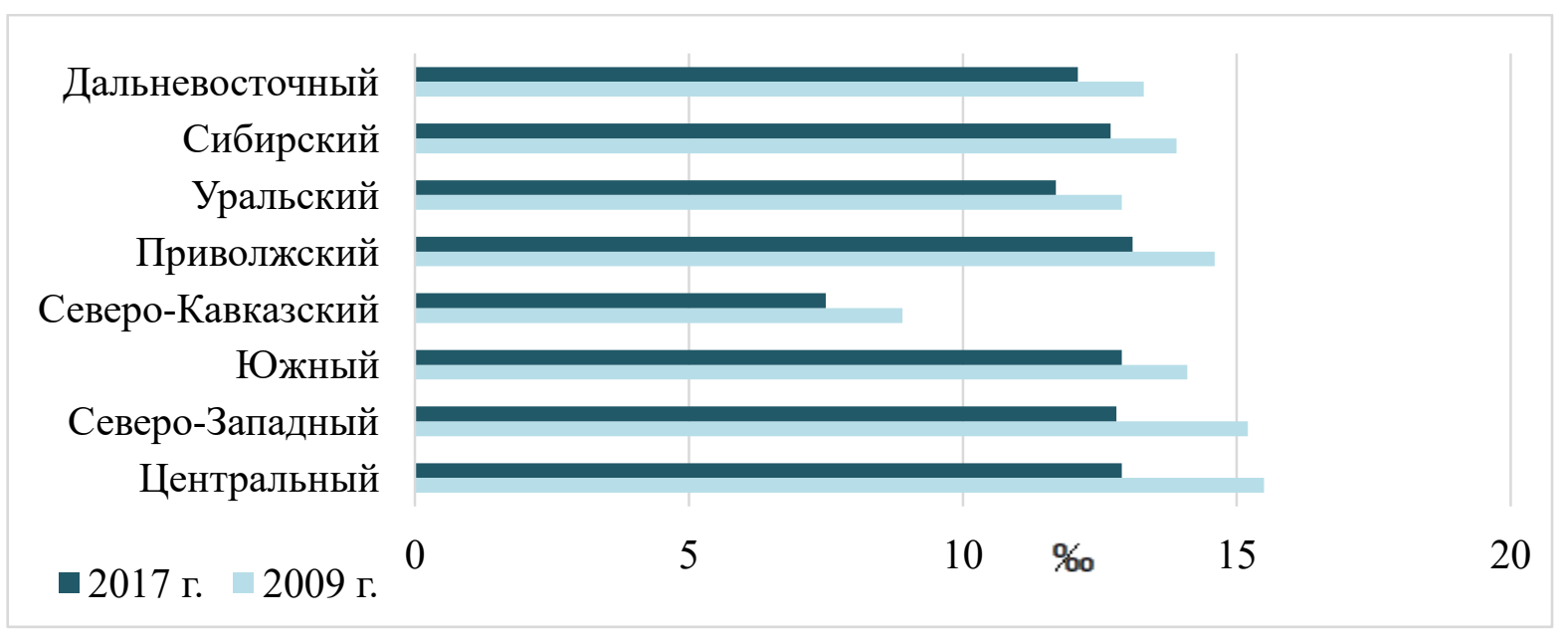

Puc. 3. Динамика общего коэффициента смертности в федеральных округах РФ, промилле 


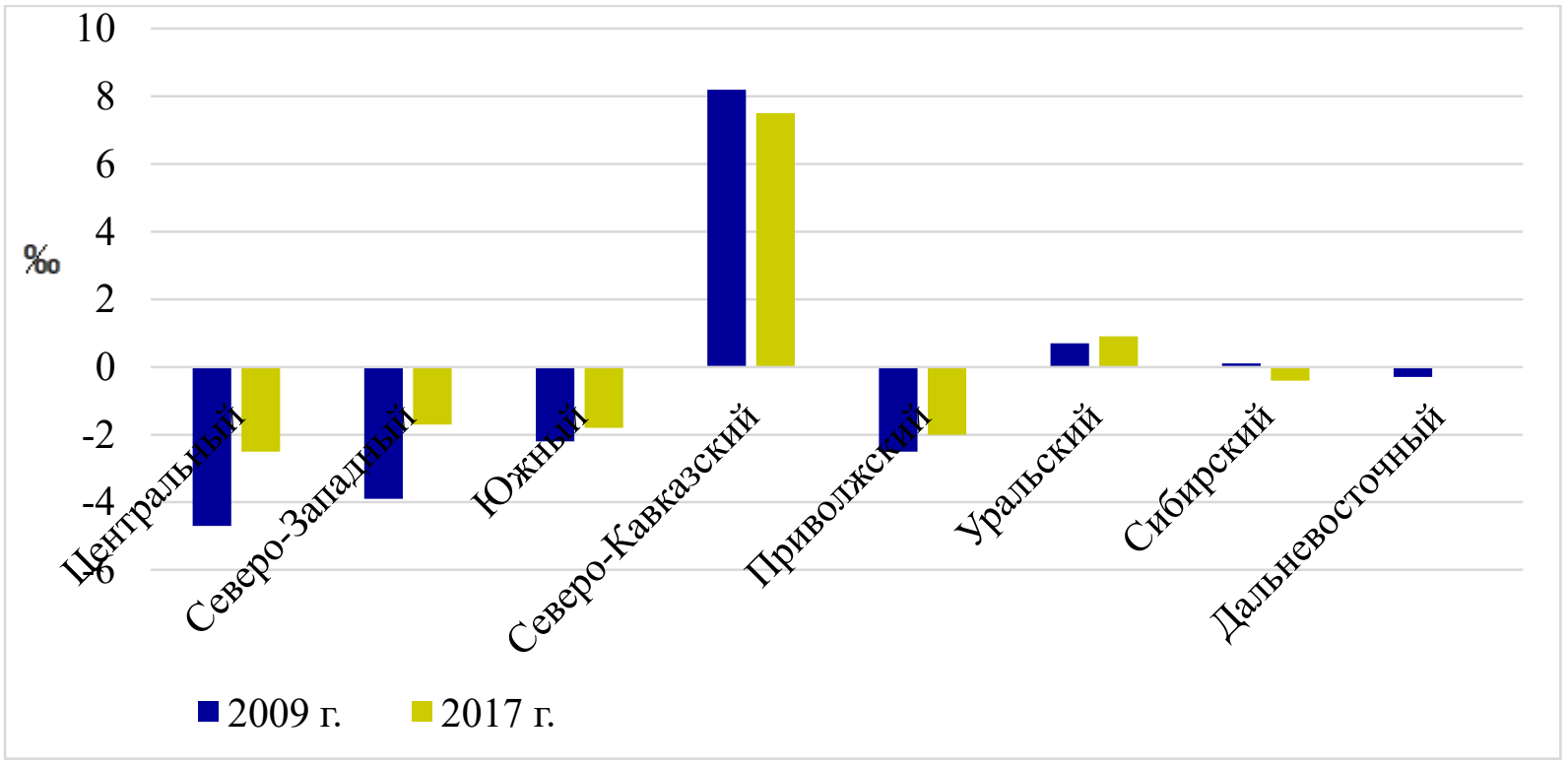

Рис. 4. Динамика коэффициента естественного прироста населения в федеральных округах РФ, промилле

(из 82) субъектах РФ сохраняется естественный прирост населения в расчете на 1000 жителей, из которых к числу «наиболее благополучных» регионов относятся Республики Дагестан $(11,3)$, Ингушетия $(13,1)$, Чеченская $(17,4)$ и Тыва $(13,2)$ (табл. 10).

На основе данных об естественном и миграционном движении населения в 2017 г. произведена группировка регионов страны. В первую группу вошли 38 субъектов РФ, в которых отмечается сокращение численности населения при естественной убыли населения и миграционном оттоке населения из региона: Республики Башкортостан, Карелия, Коми, Марий Эл, Удмуртская, Хакасия и Чувашская; Алтайский, Пермский, Приморский и Хабаровский края; Амурская, Архангельская, Брянская, Владимирская, Волгоградская, Вологодская, Ивановская, Кемеровская, Кировская, Костромская, Курганская, Курская, Липецкая, Магаданская, Мурманская, Новгородская, Омская, Оренбургская, Орловская, Пензенская, Псковская, Самарская, Саратовская, Тверская, Ульяновская, Челябинская и Еврейская автономная области.

В 12 регионах страны (Республике Мордовия; Белгородской, Воронежской, Калужской, Нижегородской, Ростовской, Рязанской, Свердловской, Смоленской, Тамбовской, Тульской и Ярославской областях) численность населения снизилась за счет превышения естественной убыли населения над миграционным приростом населения.

Превышение миграционного оттока над естественным приростом населения обусловило снижение численности населения в 9 субъектах РФ - в Республиках Калмыкия, Карачаево-Черкесской, Северная Осетия - Алания; Забайкальском и Ставропольском краях; Астраханской, Иркутской и Томской областях; Чукотском автономном округе.

Превышение естественного прироста населения над миграционным оттоком граждан привело к росту численности населения $7 \mathrm{Pe}-$ спубликах Алтай, Бурятия, Дагестан, Кабардино-Балкарская, Саха (Якутия), Тыва и Чеченская.

Рост численности населения в 8 регионах страны - Республиках Адыгея и Крым; Краснодарском крае; Калининградской, Ленинградской, Московской и Новосибирской областях и г. Севастополь - произошел за счет превышение миграционного притока населения над естественной убылью населения.

Только в 8 субъектах РФ - Республиках Ингушетия и Татарстан; Камчатском и Красноярском краях; Сахалинской и Тюменской областях; г. Москва и Санкт-Петербург - увеличение численности населения обусловлено одновременно естественным и миграционным приростом населения.

Осложнение демографической ситуации во многих субъектах РФ обусловлено снижением рождаемости населения, что во многом, по нашему мнению, связано с сокращением доходов населения.

Как отмечала О. Голодец в своем выступлении, «в связи с изменением демографической 
Таблица 10. Группировка субъектов РФ по величине коэффициента естественного прироста населения B 2017 г.

\begin{tabular}{|c|c|c|}
\hline $\begin{array}{c}\text { Коэффициент } \\
\text { естественного } \\
\text { прироста } \\
\text { населения }\end{array}$ & Федеральный округ & Субъекты РФ \\
\hline \multicolumn{3}{|l|}{$-8,0--6,0$} \\
\hline & Центральный & $\begin{array}{l}\text { Ивановская обл., Орловская обл., Смоленская обл., Тамбовская обл., } \\
\text { Тверская обл., Тульская обл. }\end{array}$ \\
\hline & Северо-Западный & Новгородская обл., Псковская обл. \\
\hline \multicolumn{3}{|l|}{$-6,0--4,0$} \\
\hline & Центральный & $\begin{array}{l}\text { Брянская обл., Владимирская обл., Воронежская обл., Костромская } \\
\text { обл., Курская обл., Липецкая обл., Рязанская обл., Ярославская обл. }\end{array}$ \\
\hline & Северо-Западный & Респ. Карелия, Ленинградская обл. \\
\hline & Приволжский & $\begin{array}{l}\text { Респ. Мордовия, Нижегородская обл., Пензенская обл., Саратовская } \\
\text { обл. }\end{array}$ \\
\hline & Уральский & Курганская обл. \\
\hline \multicolumn{3}{|l|}{$-4,0--2,0$} \\
\hline & Центральный & Белгородская обл., Калужская обл. \\
\hline & Северо-Западный & Архангельская обл., Вологодская обл. \\
\hline & Южный & Респ. Крым, Волгоградская обл., Ростовская обл. \\
\hline & Приволжский & Кировская обл., Самарская обл., Ульяновская обл. \\
\hline & Сибирский & Алтайский кр., Кемеровская обл. \\
\hline & Дальневосточный & Приморский кр. \\
\hline \multicolumn{3}{|l|}{$-2,0-0,0$} \\
\hline & Центральный & Московская обл. \\
\hline & Северо-Западный & Респ. Коми, Калининградская обл., Мурманская обл. \\
\hline & Южный & Респ. Адыгея, Краснодарский кр., г. Севастополь \\
\hline & Приволжский & $\begin{array}{l}\text { Респ. Башкортостан, Респ. Марий Эл, Удмуртская Респ., Чувашская } \\
\text { Респ., Пермский кр., Оренбургская обл. }\end{array}$ \\
\hline & Уральский & Свердловская обл., Челябинская обл. \\
\hline & Сибирский & Респ. Хакасия, Новосибирская обл., Омская обл. \\
\hline & Дальневосточный & Хабаровский кр., Амурская обл., Магаданская обл., Еврейская АО \\
\hline \multicolumn{3}{|l|}{$0,0-2,0$} \\
\hline & Центральный & г. Москва \\
\hline & Северо-Западный & г. Санкт-Петербург \\
\hline & Южный & Респ. Калмыкия, Астраханская обл. \\
\hline & Северо-Кавказский & Карачаево-Черкесская Респ., Ставропольский кр. \\
\hline & Приволжский & Респ. Татарстан \\
\hline & Сибирский & Забайкальский кр., Красноярский кр., Иркутская обл., Томская обл. \\
\hline & Дальневосточный & Камчатский кр., Сахалинская обл. \\
\hline \multicolumn{3}{|l|}{$2,0-4,0$} \\
\hline & Северо-Кавказский & Респ. Северная Осетия - Алания \\
\hline & Сибирский & Респ. Бурятия \\
\hline & Дальневосточный & Чукотский АО \\
\hline \multicolumn{3}{|l|}{$4,0-6,0$} \\
\hline & Северо-Кавказский & Кабардино-Балкарская Респ. \\
\hline \multicolumn{3}{|l|}{$6,0-8,0$} \\
\hline & Уральский & Тюменская обл. \\
\hline & Сибирский & Респ. Алтай \\
\hline & Дальневосточный & Респ. Саха (Якутия) \\
\hline \multicolumn{3}{|l|}{ более 8,0} \\
\hline & Северо-Кавказский & Респ. Дагестан, Респ. Ингушетия, Чеченская Респ. \\
\hline & Сибирский & Респ. Тыва \\
\hline
\end{tabular}

Источник. Составлено и рассчитано по данным Росстата. 
структуры нашего населения и уменьшения числа женщин фертильного возраста у нас падает рождаемость» [3].

Для улучшения демографической ситуации в стране Правительство РФ утвержден комплекс мер, включая мероприятия, направленные на повышение рождаемости, снижение смертности от предотвратимых причин, снижение материнской и младенческой смертности, регулирование миграции.

Планируется увеличение с 1 января 2018 года ежемесячных денежных выплат на первого ребенка и до достижения им полутора лет до величины прожиточного минимума соответствующего субъекта РФ [2].

В соответствии с Федеральным законом
№ 88-Ф3 от 23 апреля 2018 года освобождаются от обложения налогом доходы физических лиц ежемесячные выплаты в связи с рождением или усыновлением первого и второго ребенка [3].

Правительством РФ утвержден перечень регионов, которым в 2018 г. будут выделены дополнительные средства из федерального бюджета на ежемесячные выплаты на третьего ребенка или последующих детей, в который включены 60 регионов. А также продлено действие программы материнского (семейного) капитала до 31 декабря 2021 года; производится субсидирование ставки ипотечного кредита до 6,0\% при рождении второго ребенка и т.д. [1].

Работа выполнена при финансовой поддержке ФГБОУ ВО «РЭУ им. Г.В. Плеханова».

\section{Библиографический список}

1. Федеральный закон РФ «О субсидировании процентной ставки по ипотечным кредитам для семей с детьми» http://government.ru/docs/30909/ (дата обращения 23.04.2018 г.).

2. Федеральный закон «О ежемесячных выплатах семьям, имеющим детей» http://government.ru/activities/ selection/525/32437/ (дата обращения 23.04.2018 г.).

3. Стенограмма Вице-Премьера Правительства РФ О. Голодец. http://government.ru/news/30446/ (дата обращения 25.04.2018 г.).

4. Социальная политика, уровень и качество жизни. Словарь. Москва. 2001.

5. Бабич С.Г. Сравнительный анализ демографической ситуации в регионах РФ // В сборнике: Вестник кафедры статистики Российского экономического университета имени Г.В. Плеханова «Статистические исследования социально-экономического развития России и перспективы устойчивого роста: материалы и доклады. Под общей ред. Н.А. Садовниковой. 2018. С. 23-26.

6. Галецикй В.Ф. Демографическое развитие и его социально- экономические последствия /В.Ф. Галецкий // Пробл. прогнозирования. Москва. 2012. Вып. 5. С. 154-159.

7. Вишневский А.Г. Россия: Демографические вызовы ближайших десятилетий // Вестник наук Республики Башкортостан. 2013. Т. 18. № 1. С. 35.

8. Федеральная служба государственной статистики http://www.gks.ru/bgd/regl/b18_01/Main.htm (дата обращения 21.08.2018 г.).

9. Федеральная служба государственной статистики http://www.gks.ru/free_doc/doc_2017/demo17.pdf (дата обращения 23.08.2018 г.).

10. Федеральная служба государственной статистики http://www.gks.ru/bgd/regl/b18_01/Main.htm (дата обращения 21.04.2018 г.).

11. Федеральная служба государственной статистики http://www.gks.ru/wps/wcm/connect/rosstat_main/rosstat/ ru/statistics/population/demography/\# (дата обращения 16.08.2018 г.).

12. Федеральная служба государственной статистики http://www.gks.ru/wps/wcm/connect/rosstat_main/rosstat/ $\mathrm{ru} /$ statistics/population/demography/\# (дата обращения 25.09.2018 г.). 